\title{
AHR Roundtable
}

\section{Ending the French Wars of Religion}

\author{
ALLAN A. TULCHIN
}

ONE OF THE STRIKING PECULIARITIES ABOUT early modern wars is how intractable they were. Designations like “the Thirty Years' War" and "the Eighty Years' War" surely make the point adequately. One of the most extreme cases in this regard is the French Wars of Religion (1562-1598), in which the later Valois kings fought Protestants and radical Catholics. ${ }^{1}$ Historians have struggled to find a conceptual framework to clarify this complex narrative. The wars have traditionally been divided into eight numbered conflicts, which can be mind-numbing even for specialists. ${ }^{2}$ The wars are also famous for their horrifying massacres and assassinations, including the Saint Bartholomew's Day Massacre (1572), the most iconic act of religious violence in early modern Europe. ${ }^{3}$

Some of the older scholarship has portrayed the wars as a series of largely identical clashes that continued to reignite because France's Catholics simply refused to accept the existence of an organized Protestant movement in the country. As Pierre Miquel put it, "The Wars of Religion were not a civil war ... [The conflict] was merciless, pitting man against man. Its goal was not to dominate the adversary, but to

This article began as a paper delivered at the 2012 Western Society for French History conference in Banff, Alberta. My thanks to Jill Fehleison and Amanda Eurich, who invited me to be on the panel; to Bill Sewell for some bibliographic suggestions; and to Paul Cohen (especially), Phil Hoffman, Brian Sandberg, Rob Schneider, and the $A H R$ 's anonymous referees for reading and commenting on the manuscript at various stages.

1 The standard recent overviews of the wars are Mack P. Holt, The French Wars of Religion, 15621629 (Cambridge, 1995); Robert J. Knecht, The French Civil Wars, 1562-1598 (New York, 2000); and Arlette Jouanna et al., Histoire et dictionnaire des guerres de religion (Paris, 1998). See also Denis Crouzet, Dieu en ses royaumes: Une histoire des guerres de religion (Seyssel, 2008); Crouzet, Les guerriers de dieu: La violence au temps des troubles de religion, vers 1525-vers 1610, 2 vols. (Seyssel, 1991); and Olivia Carpi, Les guerres de religion, 1559-1598: Un conflit franco-français (Paris, 2012). The study of violence in the French Wars of Religion has also had enormous influence because of Natalie Zemon Davis, "The Rites of Violence: Religious Riot in Sixteenth-Century France," Past and Present, no. 59 (1973): 51-91, reprinted in her Society and Culture in Early Modern France: Eight Essays (Stanford, Calif., 1975), 152-188. The article's impact was recently reviewed in Graeme Murdock, Penny Roberts, and Andrew Spicer, eds., Ritual and Violence: Natalie Zemon Davis and Early Modern France, Past and Present 214, supplement 7 (2012).

2 The First War lasted from March 1562 to March 1563; the Second from September 1567 to March 1568; the Third from August 1568 to August 1570; the Fourth from October 1572 to July 1573; the Fifth from March 1574 to May 1576; the Sixth from December 1576 to September 1577; the Seventh from November 1579 to November 1580; and the Eighth from March 1585 to April 1598.

3 Arlette Jouanna, The Saint Bartholomew's Day Massacre: The Mysteries of a Crime of State, trans. Joseph Bergin (Manchester, 2013), is an excellent recent treatment. 
destroy it, to reduce it—as the inquisitors did-to ashes." ${ }^{4}$ Older works also harshly condemned the last members of the Valois dynasty-Francis II (b. 1544, r. 15591560); King Charles IX, a minor at his accession (b. 1550, r. 1560-1574); and King Henri III (b. 1551, r. 1574-1589)—for their failure to end the wars. All three kings, but especially Charles, were heavily influenced by the queen mother, Catherine de Médicis (1519-1589), the widow of King Henri II (r. 1547-1559). She was positively demonized in some older accounts. While the later Valois kings and Catherine have traditionally come in for harsh criticism, the Protestant leader Henri of Navarre, later King Henri IV (b. 1553, r. 1589-1610), is the traditional hero of the story because he successfully ended the wars in the 1590 s.

R. J. Knecht, in his judicious recent survey of the Wars of Religion, comments that explaining their duration is particularly difficult. Nonetheless, he argues that they lasted so long for three reasons. For one, the state and its revenue-raising apparatus were too weak to repress heresy effectively. In particular, the later Valois kings had great difficulty raising and paying for armed forces to repress the Huguenots. ${ }^{5}$ In addition, the various royal edicts that attempted to end the conflict were "but compromises grudgingly conceded" that satisfied no one. And finally, the many massacres and assassinations of the period embittered the parties: "The wars were also fuelled by certain acts of violence which they generated."6

Some of the reasons why ending the wars was so difficult in this period seem intuitively obvious. As Knecht notes, sixteenth-century French kings had far less control over their subjects than later monarchs and modern European states. France was a violent society at the time-recent studies suggest that murder rates in sixteenthcentury Europe were comparable to those in the most violent Latin American and Caribbean nations today. ${ }^{7}$ Religious motives also embittered the conflicts, making it harder for the parties to consider negotiated settlements. For example, religious zealotry inspired both Jacques Clément and François Ravaillac, the assassins of King Henri III and King Henri IV. ${ }^{8}$ But while endemic violence and strong religious emotions helped fuel the Wars of Religion, they do not help explain why the wars finally ended, and they provide little pattern, shape, or structure for the conflict.

Theories that might provide insight into the shape of the wars and why they ended when they did have been developed as part of the political science literature of war termination. Since the end of World War II, although deaths in wars have de-

4 "La guerre des religions n'est pas une guerre civile, comme celle des Armagnacs et des Bourguignons. Elle est inexorable, elle dresse l'homme contre l'homme. Elle n'a pas pour but de dominer l'adversaire, mais de le détruire, de le réduire—comme le font les inquisiteurs-en cendres." Pierre Miquel, Les guerres de religion (Paris, 1980), 22. Crouzet, Les guerriers de dieu, 2: 111, suggests that some of the provincial Saint Bartholomew's massacres may also have been intended to exterminate the Protestants, through either death or conversion.

5 James B. Wood, The King's Army: Warfare, Soldiers, and Society during the Wars of Religion in France, 1562-1576 (Cambridge, 1996).

${ }^{6}$ Knecht, The French Civil Wars, 292-294, quotations from 293, 294.

${ }^{7}$ Pieter Spierenburg, A History of Murder: Personal Violence in Europe from the Middle Ages to the Present (Cambridge, 2008).

${ }^{8}$ Peacemaking in the French Wars of Religion has attracted considerable interest recently; see Michel de Waele, Réconcilier les français: Henri IV et la fin des troubles de religion (1589-1598) (Quebec, 2010); Penny Roberts, Peace and Authority during the French Religious Wars, c. 1560-1600 (Basingstoke, 2013); and Jérémie Foa, Le tombeau de la paix: Une histoire des edits de pacification, 1560-1572 (Limoges, 2015). N. M. Sutherland, The Huguenot Struggle for Recognition (New Haven, Conn., 1980), uses the various edicts of pacification as the backbone of its narrative, and gives the texts in an appendix. 
clined, civil strife has dramatically escalated. Some contemporary civil wars-in Congo (Kinshasa), for example-have seemed as interminable as the French Wars of Religion, and many have also been exacerbated by similarly sharp ethnic and religious divisions. Consequently, many scholars, policymakers, and employees of nongovernmental organizations have searched very actively to understand how best to end such conflicts. Historians tend to be suspicious of models that purport to explain all civil wars, regardless of time and place. But looking at the literature of other academic disciplines is frequently helpful because it allows us to get a different perspective on the problems we examine. And just because a model may not be universally applicable does not mean that it is not helpful for a particular case.

Models from political science suggest three conclusions about the French Wars of Religion. First, they came to an end because there was a "learning curve." At the beginning of the wars, in the later 1550 s and early 1560 s, many Catholics wishfully assumed that the Protestant movement was small and weak, and with God's help it could easily be crushed. At the same time, French Protestants, based on the recent miraculous successes of their movement (which proved that they were God's Elect), confidently hoped to convert the whole country. Both sides were to be disappointed. Second, in the mid-1570s, a fragile peace emerged: the Saint Bartholomew's Day Massacre taught enough of the belligerents that they could not eliminate their opponents. They accepted a compromise that guaranteed Protestants personal security and limited rights of public worship, but put a ceiling on Protestant numbers. This peace also allowed Henri III to embark on a major reform program. As Mark Greengrass has commented, "In retrospect, it is possible to see that the French kingdom might have emerged very differently in the early seventeenth century." This negotiated peace was inherently fragile, but the wars could well have ended after the Peace of Bergerac in 1577. However, Bergerac was upended when the Valois line became extinct in 1584, making the Protestant leader Henri of Navarre the heir presumptive. ${ }^{9}$ Third, the peace that Henri IV brought about in 1598 was more stable than that of 1577 because he was not seen as a biased mediator (unlike Charles IX, Henri III, and Catherine), but rather as a victor with a particular conciliatory style that came out of his previous experiences as the leader of the minority Protestant movement. The terms of the Edict of Nantes, however, were extremely similar to those of the Peace of Bergerac.

Political SCIENTISTS HAVE IDENTIFIED Two REASOns why wars can be difficult to end that seem relevant to the Wars of Religion. First, the parties may not have accurate information about each other's strengths and weaknesses. Political scientists commonly look at war as a form of negotiation or bargaining, and conceptualize wars as the result of a lack of adequate information. If each side could accurately assess its strength relative to the other, they would come to an agreement. Unfortunately, leaders have a tendency to overestimate their abilities, and therefore to reject compro-

${ }_{9}^{9}$ Mark Greengrass, Governing Passions: Peace and Reform in the French Kingdom, 1576-1585 (Oxford, 2007), 365; H. G. Koenigsberger, "The French Succession and the War with England," in The New Cambridge Modern History, vol. 3: R. B. Wernham, ed., Counter-Reformation and Price Revolution, 15591610 (Cambridge, 1968), 294-318, here 295, also notes the pause in the conflict. 
mise.$^{10}$ From this perspective, wars are learning experiences, and they end when battles prove which side is the stronger to both sides' satisfaction. Another reason why it can be difficult to end a war is that it may be hard for the warring parties to absorb the lessons of their experience. Even if those on one side learn that theirs is the weaker party, as Dan Reiter has emphasized, they may still be reluctant to settle if they do not believe that the other side will abide by the agreement. They may feel forced to continue fighting despite poor performance on the battlefield. ${ }^{11}$ A peace agreement is meaningless without enforcement mechanisms. Barbara Walter has argued that external mediators are crucial to ending civil wars, because parties will not agree to a peace that they do not believe can be enforced. ${ }^{12}$

In addition to these general considerations, there are some beliefs specific to the period that helped prolong the Wars of Religion because they prevented the parties from gaining an understanding of their situation. Sixteenth-century understandings of the role of the monarchy, for instance, inhibited compromise. Many Catholics were initially reluctant to accept a compromise peace because they believed royal rhetoric that exaggerated the king's power and his ability to dictate the course of events. For example, in 1564, Charles IX went on a tour of France to pacify the country. ${ }^{13}$ He was fêted with elaborate pageantry. In Lyon, he was greeted as a new Josiah, the biblical king of Judah, able to purify the nation despite his youth. Onlookers were assured that "all power and dominion is ordered and established by God, which [power] we must obey, not only out of fear, but for conscience; especially since whoever resists it, contradicts Divine authority." 14 The judges of the Paris Parlement (France's highest court) had even more reasons to resist compromises that suggested Charles IX was unable to enforce the law after seeing the king clothe himself in such heroic garb.

Religious beliefs also made the parties reluctant to admit the need for compromise: many French Catholics and Protestants expected God to intervene to ensure that the righteous side would win. In 1560 the Dominican Pierre Dyvolé prophesied that "ruin and desolation would soon come because of the Huguenots, seditious rebels against God, the crown, and the public tranquility of France." 15 Given that many French people believed that God actively intervened in this world to protect His church, it was essential that heresy (or papist idolatry) be eliminated before divine wrath brought disaster to the kingdom. Those sixteenth-century French people who

${ }^{10}$ James D. Fearon, "Rationalist Explanations for War," International Organization 49, no. 3 (Summer 1995): 379-414.

${ }^{11}$ Dan Reiter, How Wars End (Princeton, N.J., 2009), 15, and more generally chap. 3.

${ }^{12}$ Barbara F. Walter, Committing to Peace: The Successful Settlement of Civil Wars (Princeton, N.J., 2002).

13 Jean Boutier, Alain Dewerpe, and Daniel Nordman, Un tour de France royal: Le voyage de Charles IX, 1564-1566 (Paris, 1984).

${ }^{14}$ Discours de l'entree de tresillvstre, trespuissant, treschrestien, \& tres-victorieux Prince Charles de Valois neufuiéme de ce nom Roy de France, en sa trescelebre \& fameuse ville de Lyon, faicte le treziéme iour de Iuin, Mil cinq cens soixante quatre (Lyon, 1564), f. Aiii. In French: "toute puissance \& domination est ordonnee \& etablie de Dieu, à lqauelle il faut obeir, non seulement pour la crainte, ains pour la conscience: d'autant que qui luy resiste, contredit à la volonté Divine.” I found this reference via Roberts, Peace and Authority during the French Religious Wars, 98-99.

15 Cited in de Waele, Réconcilier les français, 54-55. In French: "prophetisa à la France sa ruyne et desolation proche à advenir par iceux huguenotz et seditieux rebelles contre Dieu, la coronne et le repos public de France." 
believed that God and King had the power to bring about victory must have found it hard to assimilate the information coming from the battlefield and to come to a just appreciation of their position.

Still, as Reiter's model suggests should have occurred, there does appear to have been a slow learning process for both sides in the early stages of the Wars of Religion. At the outset, many Catholics grossly overestimated their strength. Many would have agreed with Blaise de Monluc, a great writer and notable captain in Guyenne (southwestern France), who insisted in late March 1562 that "whatever some might say, the [Protestant] religion is so inferior in the number of men that it is no more than one-tenth the size of the Catholic in Guyenne, so that should one wish to exterminate it, it could easily now be done." 16 This assessment was quite wrong: Guyenne was one of the great Protestant strongholds. One indication that Catholics initially had poor knowledge of the two religions' relative strength was that at the outset of the wars in 1561-1563, they were prepared to massacre Protestants without thinking about the risks that this policy entailed. These massacres were concentrated in the upper Garonne region around Toulouse and in a broad belt south and southeast of Paris.

Massacres are clear markers of poor information, and as Stathis Kalyvas has argued, such "indiscriminate violence" is therefore particularly common at the beginning of a civil war. ${ }^{17}$ The massacre at Wassy, perpetrated by men under the command of the Duke of Guise, is perhaps the most famous of the mass killings of this period, and traditionally labeled as the opening salvo of the wars. Massacres actually began at least three months before Wassy, in Carcassonne and Grenade. The violence was frequently heavily ritualized. At Carcassonne, a Protestant source reports that "Guiraud Bertrand [a Protestant] was also inhumanely killed, and [afterward] one of the rioters split open his mouth with a dagger and then put the bit from a bridle inside, and a book in his hands." 18 It is possible that Protestants declared war after Wassy, rather than previous massacres, because Guise's leadership of the massacre there convinced Protestants that there was an organized campaign to eliminate them, rather than just a series of isolated random incidents. But Catholics did not see the dangers: when Guise entered Paris, he was acclaimed as a "second Moses."19

If some Catholics initially assumed that they could kill Protestants with impunity, they soon learned otherwise. After papal troops from Avignon massacred Protestants in Orange, Protestants seized the chateau of the village of Mornas and massacred

${ }^{16}$ Memoires de Condé, servant d'éclaircissement et de preuves à l'Histoire de M. de Thou: Contenant ce qui s'est passé de plus mémorable en Europe, 6 vols. (Paris, 1743), 3: 184. In French: "Ladicte Religion [Protestante] (quoyqu'on en dye) est si inferieurre de nombre d'hommes audict Païs de Guyene, à celle de l'Eglise Romaine, de plus de la dix ${ }^{\mathrm{me}}$ partye; tellement que qui la voudroit exterminer, on le pourroit encores maintenant aisement faire." I found this reference via Roberts, Peace and Authority during the French Religious Wars, 61.

${ }^{17}$ Stathis N. Kalyvas, The Logic of Violence in Civil War (Cambridge, 2006), especially chap. 6. For a list of all the massacres, see my article "Massacres during the French Wars of Religion," Past and Present 214, supplement 7 (2012): 100-126, here 106-108.

18 Théodore de Bèze, Histoire ecclésiastique des églises réformées au royaume de France, ed. G. Baum and Ed. Cunitz, 3 vols. (Paris, 1883), 1: 964. In French: "Guiraud Bertrand y fut aussi inhumainement tué, auquel un des seditieux fendit la bouche avec une dague \& puis luy mit un mords de bride dedans, \& un livre entre les mains.”

19 Jouanna, Histoire et dictionnaire des guerres de religion, 110. 
the inhabitants, shouting, "Kill, kill! Let them pay for Orange!" They dumped the bodies into a boat, which was set adrift to float down the Rhône toward Avignon with a message attached to it reading: "O you people of Avignon! Let these merchants pass, since they have already paid duty at Mornas." 20 As a result of this and similar incidents, Catholic massacres of Protestants declined precipitously after Charles IX signed the Peace of Amboise in 1563. To some extent, massacres may have declined because minority religious communities learned to defend themselves or leave the area. But in many cases they remained in place, and vulnerable to attack-in Rennes and Bordeaux, for example. It seems more reasonable to infer that perpetrators concluded that massacres were ineffective or worse-the Bordeaux authorities in particular were well aware that Henri of Navarre's troops were close at hand. ${ }^{21}$ In short, as political scientists would have predicted, Catholics learned.

Although after 1563 Catholic forces learned the costs of perpetrating indiscriminate violence, many Catholics were still highly reluctant to acknowledge explicitly the possibility that the Protestant heresy would become a permanent feature of French society. The Parlement of Paris refused to register the Edict of Amboise. The Parlement's first president, Christophe de Thou (father of the great historian JacquesAuguste de Thou), insisted that the edict contained provisions that in effect authorized two religions in France, "which would utterly break and destroy society, for religious unity is the ligament of states." 22 He saw Catholicism as a crucial glue; only the elimination of heresy could permanently end the conflict. Mack Holt concludes, "While the aims of those like the Queen Mother and Michel de l'Hôpital to pursue peace through religious toleration rather than persecution are commendable, they were unrealistic in the 1560s (though by that time a renewal of the repression of Henri II would not have been any more effective)." As Holt describes it, Catherine de Médicis, the leading figure in Charles IX's government, faced an impossible task: she and her advisers were unable either to repress Protestantism or to force Catholics to accept a compromise with Protestants. While Holt's argument has some merit, "unrealistic" is perhaps too strong. Although the Parlement of Paris refused to register the Edict of Amboise, Catherine was able to push through registration at a number of other provincial parlements - and violence did end. As Knecht concludes, "The policy of limited religious toleration pursued by the French government since March 1563 [the date of the Edict of Amboise] seemed to be working quite well. By January 1567 France was more or less at peace." 23

If by 1563 many Catholic militants had learned to moderate their tactics, Protestants had not learned to moderate their demands and trust their opponents. Reiter's

\footnotetext{
${ }^{20}$ Gustave Lambert, Histoire des guerres de religion en Provence (1530-1598), 2 vols. (Toulon, 1870), 1: 159-161. In Provençal: "O voi d'Avignone! Lasciate passare questi mercanti, perche an pagato il dazio a Mornas."

${ }^{21}$ Jean Meyer, ed., Histoire de Rennes (Toulouse, 1972); Robert Boutruche, ed., Bordeaux de 1453 à 1715 (Bordeaux, 1966), 249-250.

22 Édouard Maugis, Histoire du Parlement de Paris: De l'avènement des rois Valois à la mort d'Henri IV, vol. 2: Période des guerres de religion de la Ligue et de Henri IV (Paris, 1913), 32-33. In French: "dont la société sera entièrement violée et dissolue, l'unité de religion étant le lien des États."

${ }^{23}$ Holt, The French Wars of Religion, 193; Knecht, The French Civil Wars, 133. Roberts, Peace and Authority during the French Religious Wars, 33, goes so far as to say that "the Edict of Amboise instituted the most extended, and arguably the most successful, peace prior to that heralded by the Edict of Nantes at the end of the century."
} 
argument that parties will not sign agreements that they believe will not be enforced seems particularly relevant here. Protestants started most of the eight wars, but they frequently had very good cause-the later Valois kings could not prevent massacres, enforce peace agreements, or punish Catholic violators. In 1567, however, the Protestants, driven by hope and insecurity, started the Second War of Religion without an actual casus belli. In 1565, Catherine de Médicis went to Bayonne to marry her daughter Elizabeth to King Philip II of Spain. Philip did not attend in person, so the Duke of Alva took his place at the ceremony. The Dutch revolt broke out in 1566, and Philip sent the Duke of Alva from Italy to the Netherlands with an army to suppress it. His route necessarily passed along the entire French border with the Holy Roman Empire. Protestants worried that Catherine de Médicis's decision to hire 6,000 Swiss mercenaries was part of a plot concocted with the Duke of Alva to destroy them. This highlights the importance of Walter's point that external mediators can be crucial. In the Wars of Religion, no trustworthy external mediator was available because Charles IX and Catherine were deeply implicated in the conflict. Instead, Protestants pinned their hopes on seizing control of the court and converting the young king, and with his influence the whole country, to Protestantism. Possessed of The Truth, they could not understand why Charles would not convert to their religion. In 1567, Protestants anxious about Alva and Catherine tried to kidnap the king while he was traveling near Meaux, despite all of Catherine's efforts to conciliate them over the previous four years. ${ }^{24}$ Protestants also staged a series of massacres of their own. The most famous of these, called the Michelade, occurred in Nîmes, where contemporary sources record upwards of one hundred deaths. The massacre was led by a junta called the "Messieurs," consisting of virtually all of Nîmes's Protestant political leaders. Jean de Sauzet, one of the Messieurs, still felt that only total victory was an acceptable outcome. Explaining why the Messieurs ordered the destruction of nearly every Catholic church in town, he is reported to have said, "The nests must be destroyed so that the birds will not return." 25 Catholic counter-massacres of Protestants followed in the wake of these attacks.

The later Valois kings functioned as biased mediators, able to offer carrots to both Catholics and Protestants, but sticks only to the latter. They were reluctant to punish Catholics who broke peace agreements because Catholics were the overwhelming majority of the population, and France's king and queen mother agreed with Catholic forces that in an ideal world, there would be no Protestants in France. Many Catholics may have been dissuaded from using massacres as a tactic after the massacres of 1561-1563 failed to destroy Protestantism in France. But some Catholics were still tempted by it because of the unique circumstances of 1572 , when the

${ }^{24}$ This was actually their second attempt. In 1560, Protestant noblemen became convinced that Francis II was caught in an echo chamber at court where he could not have a proper opportunity to hear the Protestant message, so in 1560 they attempted to kidnap him. See Henri Naef, La conjuration d'Amboise et Genève (Geneva, 1922).

${ }_{25}$ On the "surprise at Meaux," see James Westfall Thompson, The Wars of Religion in France, 15591576: The Huguenots, Catherine de Medici and Philip II (Chicago, 1909), 318-321; on the massacre in Nîmes, see Allan A. Tulchin, "The Michelade in Nîmes, 1567," French Historical Studies 29, no. 1 (2006): 1-36. The de Sauzet quote comes from a contemporary deposition: Archives Départementales du Gard, G 442, fol. 97v. In French: "il falloit tumber le nid affin q[ue] les oyseaulx ne y retournassent." For an example of a Catholic massacre of Protestants in Auxerre, see Olivier Jacques Chardon, Histoire de la ville d'Auxerre, 2 vols. (Auxerre, 1834, 1835), 1: 228-233. 
bulk of the Protestant leadership gathered in Paris for the royal wedding of Charles IX's sister Marguerite de Valois to Henri of Navarre. Charles IX, the Protestant leaders, and many subsequent historians have concluded that the Duke of Guise was responsible for the attempted assassination of Admiral Gaspard de Coligny, the Protestant leader, on August 22, 1572. But the king, the queen mother, and the council preferred to massacre Protestant leaders rather than punish the duke. ${ }^{26}$ Royal policy in the Wars of Religion was somewhat contradictory: Charles IX and Henri III negotiated compromises while frequently insisting that Protestantism was a heresy that in principle should be illegal. Of course, perfect consistency was impossible in the period 1559-1589, since there were three kings and many officials and noblemen competing to influence them. Nonetheless, there was consistency in at least one respect: no king was ever willing to execute Catholic murderers of Protestants. Had the later Valois kings been willing to punish Catholic groups that committed massacres, Catholics would surely have learned to behave themselves more rapidly. ${ }^{27}$ On the other hand, the Protestant movement could not be crushed; nor could it be prevented from resorting to war when the alternative was massacre at Catholic hands. It should also be noted that despite her biased position, Catherine de Médicis was a master negotiator, and her skills undoubtedly helped reduce the violence. ${ }^{28}$

By THE LATE 1560s, MOST IMPARTIAL OBSERVERS would have concluded that Protestantism was never destined to become the majority religion in France. At the same time, the movement survived the Saint Bartholomew Day's Massacre, which at least in retrospect strongly suggests that the resources to eliminate Protestantism did not exist. One of the reasons why so many Protestants were killed during that wave of violence was that they thought it unlikely that Catholics would attempt a massacre right after the king and queen mother had staged an elaborate royal wedding that enacted national reconciliation. However, the Protestants also no longer expected Catholics to use a tactic whose efficacy had already been found wanting. In any case, Protestant survival after 1572 proved that massacres did not work: they virtually ceased thereafter. Most infuriating for Catholics, the Protestant position even seemed to improve. Royal forces soon found themselves facing a Protestant army twice their size, with the king's own brother and heir presumptive, François Duke of Anjou (1555-1584), among its leaders.

The Saint Bartholomew's Day Massacre thus paradoxically led both sides to recognize that total victory was impossible, and made peace more likely. Although Catholics refused to abide by the Peace of Monsieur (1576), the first peace signed after

${ }^{26}$ Jouanna, The Saint Bartholomew's Day Massacre, 89-106. Note that Jouanna's interpretation is different from the one proffered here.

27 This paragraph skips over the complicated and contentious question of who, exactly, was behind the Saint Bartholomew's Massacre. Jouanna, The Saint Bartholomew's Day Massacre, 128, argues that the Parisian crowd committed the massacre on its own because of a "tragic misunderstanding" of a remark by the Duke of Guise. I believe Guise was more deeply involved. But in any case, no one doubts that Catholics were the killers.

${ }^{28}$ See, for example, Denis Crouzet, "Catherine de Médicis actrice d'une mutation dans l'imaginaire politique (1578-1579)," in Didier Boisson and Yves Krumenacker, eds., La coexistence confessionnelle à l'épreuve: Études sur les relations entre protestants et catholiques dans la France moderne (Lyon, 2009), $17-50$. 
Saint Bartholomew's, it did largely abide by the second, the Peace of Bergerac (1577). Even Monluc, who at the start of the wars had called for the immediate extermination of the Protestants, wrote a long "Discours" in 1573 in which he urged the king to allow the Protestants to observe their faith, and to bring the wars to an end. ${ }^{29}$ As Michel de Waele concludes, "From 1577 to 1584, France lived in relative calm."30 There was one very limited outbreak of civil war, the Seventh War of Religion, in this period, but as Mack Holt agrees, it was "the shortest and least significant" of them. As Holt emphasizes, there were also a number of peasant revolts, but these were confined to the southeast, and in any case peasant revolts were endemic under the Old Regime. ${ }^{31}$ The peace was fragile, but it was real.

When the provisions of the Peace of Monsieur are compared to those of the Peace of Bergerac, it seems clear that Catholics defiantly rejected the first but grudgingly accepted the second because, although Bergerac permitted Protestant worship, it put tight boundaries around Protestant growth. Of all the agreements signed in the sixteenth century, the Peace of Monsieur was the most favorable to the Protestant cause. If that was not enough to make many Catholics reject it, they also felt that its provisions did not accurately reflect the balance of power between the parties. Rather, they were convinced, as indeed was Henri III, that he had signed the peace because he felt temporarily constrained by the mutiny of his brother Anjou. Although the Peace of Monsieur did not give Protestants full equality (for example, it called Protestantism the "so-called Reformed religion"), the provisions were nonetheless generous. Protestants obtained freedom of worship everywhere in France with the exception of Paris and its immediate environs. To prevent discrimination in the courts, they were given special chambres mi-parties (bipartisan tribunals) in every Parlement, a major conceptual innovation. They also obtained eight lieux de sûreté (places of safety) - towns where they were permitted to maintain their own private armies. Moreover, the peace also included a provision calling for a meeting of the Estates-General. This provision backfired. Protestants had long believed in constitutional government, and they had organized a campaign in 1561 to demand regular meetings of the Estates. However, Catholics secured a clear majority in the elections, and used the Estates to disrupt the peace. ${ }^{32}$

By contrast, the Peace of Bergerac prevented France's Protestants from building more than a handful of new churches. It retained most of the text of the Peace of Monsieur, with the crucial exception that it permitted Protestant worship only in places the Protestants held as of September 17, 1577, plus one town per bailliage (an administrative district roughly the size of a modern département). Since most bailliages

\footnotetext{
${ }^{29}$ Solange Deyon, "Blaise de Monluc, la guerre, la paix," Bulletin de la société de l'histoire du protestantisme français 150, no. 2 (2004): 245-256, cited in Roberts, Peace and Authority during the French Religious Wars, 122.

${ }^{30}$ De Waele, Réconcilier les français, 73. For a different point of view, see Holt, The French Wars of Religion, 111, who argues that after the Peace of Bergerac, "if [Henri III] was unable to sustain a war long enough to defeat the Huguenots, he was equally incapable of maintaining peace for any extended period."

${ }^{31}$ Holt, The French Wars of Religion, 111-116, quotation from 116.

32 On 1561, see Noël Valois, "Les essais de conciliation religieuse au début du règne de Charles IX," Revue d'histoire de l'Église de France 31, no. 119 (1945): 237-276; on 1576, see Mack P. Holt, "Attitudes of the French Nobility at the Estates-General of 1576," Sixteenth Century Journal 18, no. 4 (1987): 489504.
} 
already had at least one Protestant church, this second provision did not really permit any Protestant growth. ${ }^{33}$ Protestants could no longer hope, nor Catholics fear, that the majority of the population would convert to the new religion. Only four of the chambres mi-parties were retained, but the subsequent success of the peace suggests that Catholics had learned at a fundamental level that religious uniformity was incompatible with political unity or social peace.

The best evidence that contemporaries thought that peace was at hand is in the recent magisterial book Governing Passions: Peace and Reform in the French Kingdom, 1576-1585, by Mark Greengrass. He shows that Henri III and Catherine used the period of peace after 1577 to undertake extensive efforts to reform France's institutions. They worked to end inflation, passed the Ordinance of Blois (the most important legal reform of the century) in 1579, sent out commissioners to inspect local officials, and began a process that was supposed to lead to the end of the sale of offices. Contemporaries understood that such desirable reforms could not succeed without peace, and indeed a major reason the king and queen mother undertook the program was that they knew that all the parties desired the reforms. The reforms were the carrots that would get the parties to accept the peace. ${ }^{34}$ Had Henri III and his brother Anjou not died without heirs, the fragile peace could well have taken hold.

If IT IS TRUe THAT THE WARS OF ReLigion could have ended in 1577, why did they not do so, and why did they finally end in 1598? Monica Duffy Toft's work suggests that the 1577 settlement had an inherent weakness, and Henri IV had an inherent strength that the later Valois kings lacked. One of Toft's key contentions is that negotiated settlements to civil wars break down far more frequently than when one side wins. She concludes that this occurs because in order for a negotiated settlement to last, each side must face both carrots and sticks for violating the agreement, and negotiated settlements commonly offer only carrots: "well-intentioned third parties who are interested in facilitating enduring peace must consider adding credible enforcement mechanisms - a threat of harm-to any cease-fire or peace agreement." Of course, a "credible enforcement mechanism" usually means that there must be armed military and police forces capable of punishing defectors. When one side wins, by contrast, its security forces are usually capable of punishing the other side if it tries to get out of the agreement. ${ }^{35}$ In the subset of cases where one side won, Toft compares conflicts in which the government won to those in which insurgents won. She concludes that when insurgents prevailed, outcomes were distinctly better for the countries concerned: twenty years later, those countries were less likely to have a

\footnotetext{
${ }^{33}$ Since there were only about 86 bailliages in France, and approximately 20 million inhabitants, a bailliage on average had a population of somewhat less than 250,000, On the number of bailliages, see Roger Doucet, Les institutions de la France au XVI e siècle (Paris, 1948), 171. No precise French population figures exist, but the standard source is Jacques Dupâquier, Histoire de la population française, 4 vols. (Paris, 1988). On the number of French Protestant churches, see Philip Benedict and Nicolas Fornerod, "Les 2150 'églises' réformées de France de 1561-1562," Revue historique 311 (2009): 529-560.

34 Greengrass, Governing Passions.

${ }^{35}$ Monica Duffy Toft, Securing the Peace: The Durable Settlement of Civil Wars (Princeton, N.J., 2010), 43.
} 
renewed outbreak of conflict, they scored higher on an index of democracy, and economic growth was slightly higher as well. She argues that insurgents frequently make up for their inferior assets by trying to mobilize broad community support. When they win, they tend to bring a more open style of decision-making to the government. ${ }^{36}$ Toft's model cannot be used here without modifications: she presumes a two-sided struggle between the "government" and "insurgents," while the French Wars of Religion were at least three-sided, as are many modern civil conflicts-but her argument about insurgent style seems relevant.

The death of Anjou disrupted the structural arc of the wars. Instead of a continuing peacemaking process, the key questions were immediately reopened, and the whole cycle began again, with even more viciousness since everyone thought they had been settled. The Catholic League, which had been quiescent since the Estates-General of 1576, enjoyed a renaissance and developed into the biggest political organization in the country, with powerful aristocratic patronage capable of challenging Henri III. Catholics were determined to unite because it appeared possible that France could turn Protestant, since Henri of Navarre, the leader of the Protestants, was now the heir presumptive. Catholic political theorists suddenly reversed their positions and began to write in favor of the right of resistance to tyrants; Protestants began to preach obedience to kings. The Eighth War of Religion, particularly in the period immediately after Henri III's assassination, witnessed some of the most sustained and bloody fighting of the period. As de Waele puts it, the situation "put France face to face with a fundamental contradiction." ${ }^{37}$ Furthermore, the new situation dramatically reduced Henri III's ability to influence events, since both the Protestants and the Catholic League were bound to wait to see what would happen after his death and Henri of Navarre's accession. In 1588, Henri III, in extreme frustration and desperation, ordered the killing of Henri, Duke of Guise, and his brother, the Cardinal de Guise, before being himself assassinated the following year. Thus it is reasonable to divide the Wars of Religion into two groups: the first seven, which led slowly to a fragile peace, and the eighth, which lasted as long as the first seven combined, but which led to a firmer peace based on similar principles. In the short term, Catholics decided on war when Henri of Navarre became the heir presumptive; in the medium term, Henri IV proved to be in a better position to make peace than either Henri III or Catherine.

In addition to upsetting the Peace of Bergerac, when Henri of Navarre became the heir presumptive of Henri III and then Henri IV, he went from being the leader of an insurgent party to being the head of the government. It is true that this legitimacy was contested: his League opponents argued that he had no right to be king, since the pope had excommunicated him and declared him unfit to rule; even Henri III's position was somewhat unstable, for the same reasons- the pope and the Sorbonne had declared him unfit as well. But on the other hand, Henri of Navarre was next in line to the throne, and Henri III, before dying of his wounds, named him his heir. Many of Henri IV's troops were Catholic, and under considerable pressure

36 Ibid., 62-69. My analysis in this and the next paragraph was improved by conversations with Hilary Bernstein.

${ }^{37}$ De Waele, Réconcilier les français, 85; Jouanna, Histoire et dictionnaire des guerres de religion, $241,253$. 
from public opinion, in 1593 he converted to Catholicism. His position gave him considerable legitimacy. The Catholic League was more plausibly the insurgent party in this phase of the wars.

Nonetheless, Henry IV continued to use a different, less authoritarian style than Henri III, similar to what Toft suggests is typical for insurgent victors. His reign was also notably successful at bringing peace, and with it improved living conditions, for the country. Henri's informal, warmer style arguably stems from his previous experience as the leader of an insurgency. When the Paris Parlement sent a delegation to him to protest against registering the Edict of Nantes (1598), just as they had with the Edict of Amboise a generation earlier, Henri pointed out to them:

You see me in my study, where I have come to speak to you, not dressed in royal attire with sword and cape like my predecessors, nor like a prince who has come to speak with foreign ambassadors, but dressed in a simple doublet, like the father of a family speaking intimately with his children. What I have to say to you is that I want you to verify the edict. $^{38}$

Fundamentally, Henri IV was giving the judges an order, but he couched it in a way designed to soften that fact, and to distinguish himself sharply from his predecessors. This is the kind of language Henri had learned to use when he had to negotiate with the fissiparous towns and synods of the Protestant movement. It also may stem from a tradition of noble revolt where high nobles claimed to be acting in defense of traditional liberties.

Although many aspects of the Wars of Religion are contentious, analyses of Henri IV's policies after his conversion are in accord: Henri triumphed above all by being generous to his former enemies. For example, the Duke of Mayenne is reported to have received 3,580,000 livres tournois, Claude de la Châtre 900,000 l.t., and the Duke of Lorraine 3,766,825 l.t. Most surveys cite Henri IV's minister the Duke of Sully, who stated that Henri spent 32,000,000 l.t. on bribes given to League leaders. ${ }^{39}$ Towns that submitted had their privileges extended and their taxes reduced. Noble former members of the Catholic League were also rewarded with high office, sometimes to such an extent that old friends of the king felt slighted. Occasionally, rebellious towns such as Laon and Amiens had to be given rough medicine, to serve as examples to others. ${ }^{40}$ This also meshes well with Toft's model.

Toft's model might need modification, however, in one other respect. It was certainly reasonable for Henri to try to appear to be generous, but given that the royal finances were in dire straits at his accession, there were also good reasons to limit his generosity. Sully used very rough measures to bring the royal budget into line. Creditors were forced to wait almost indefinitely (until they died, if possible), the interest rates on their loans were arbitrarily reduced, and they were offered repayment of principal only if they would agree to discount it severely. Henri IV had a reputation for being a cheapskate compared to his predecessors (except when it came to his mistresses). Jacques Bongars, the French ambassador to the German princes, did not

${ }^{38}$ Quoted in Holt, The French Wars of Religion, 167.

${ }^{39}$ Jouanna, Histoire et dictionnaire des guerres de religion, 398-399.

40 On Laon and Amiens, see ibid., 394 and 406, and more generally S. Annette Finley-Crosswhite, Henry IV and the Towns: The Pursuit of Legitimacy in French Urban Society, 1589-1610 (Cambridge, 1999). 
get paid for twenty years. ${ }^{41}$ In short, Henri's policy was to proclaim his munificence while in reality he was most reluctant to actually pay up.

A crucial piece of evidence showing the basic solidity of the 1577 settlement is that Henri IV essentially adopted its provisions in the Edict of Nantes. Crucially, the edict provided that Protestant worship could take place only in those cities where it had occurred in August 1597, plus in two towns per bailliage and on noble estates. ${ }^{42}$ The former Protestant leader Henri IV was barely more generous to the Protestants than the Catholic Catherine, probably because he calculated that French Catholics would not stand for much more. Nantes, like Bergerac, put a ceiling on French Protestant aspirations. Public life in France remained essentially Catholic, and if Henri IV did not force his Protestant subjects to convert, he certainly used moral suasion and the force of his own example to encourage them to do so. The Edict of Nantes in popular memory represents a monument of toleration, but this is a myth and does not capture the edict's true importance. Rather, although Henri IV, like all sixteenth-century monarchs, had continuing difficulties asserting his authority, he achieved in the Edict of Nantes a lasting peace. ${ }^{43}$

THE POLITICAL SCIENCE LITERATURE CAN HELP US step back and gain greater conceptual clarity about the shape of the Wars of Religion, why they lasted so long, why they finally ended, and on what terms. Over the course of the wars, there was in fact a learning curve whereby the parties gradually gained a better understanding of each other's strengths. This then led to a quasi-peace between 1577 and 1584, which was weak but might have held had Henri III not been childless. In addition, Henri IV's victory was more likely to endure than a victory by the Catholic League or a negotiated truce because Henri had a more open political style shaped by his previous career as head of an insurgency. The peace settlement and Henri's conversion limited Protestant political aspirations. It also encouraged diehard Catholics to continue to hope that eventually the state might grow strong enough to eliminate heresy from the realm. Despite Henri's more open style, his victory helped re-burnish the ideal of the absolute monarchy.

41 Jean-Pierre Babelon, Henri IV (Paris, 1982), 744-748, 883-884.

42 Gregory Champeaud, "The Edict of Poitiers and the Treaty of Nerac, or Two Steps towards the Edict of Nantes," Sixteenth Century Journal 32, no. 2 (2001): 319-334.

${ }^{43}$ Holt, The French Wars of Religion, 163, 172.

\begin{abstract}
Allan A. Tulchin is a historian of early modern France, with particular interests in religion, toleration, violence, social history, and gender and sexuality. He completed his undergraduate education at Yale and Cambridge, and his doctorate at the University of Chicago. He is the author of That Men Would Praise the Lord: The Triumph of Protestantism in Nîmes, 1530-1570 (Oxford, 2010). His research has also been published in French Historical Studies (2006), the Journal of Modern History (2007 and 2014), Past and Present (2012), and the Sixteenth Century Journal (2013). He is an Associate Professor of History at Shippensburg University. He is currently writing a book analyzing the spread of the Enlightenment in Bordeaux.
\end{abstract}


Copyright of American Historical Review is the property of Oxford University Press / USA and its content may not be copied or emailed to multiple sites or posted to a listserv without the copyright holder's express written permission. However, users may print, download, or email articles for individual use. 